\title{
Synthesis of Hydroxyapatite from Crab Shell (Scylla serrata) Waste With Different Methods Added Phosphate
}

\author{
Sari Edi Cahyaningrum*, Nuniek Herdyastuty, Fenty Wiana, Bella Devina and Dicky Supangat \\ Department of Chemistry, Faculty Mathematics and Natural Science \\ Universitas Negeri Surabaya \\ Surabaya, Indonesia \\ saricahyaningrum@unesa.ac.id
}

\begin{abstract}
Hydroxyapatite (HAp) is the main material of bone structure which has chemical formula $\mathrm{Ca}_{10}\left(\mathrm{PO}_{4}\right)_{6}(\mathrm{OH})_{2}$. In this research, HAp synthesis use precursor calcium from crab shells and phosphate from $\mathrm{H}_{3} \mathrm{PO}_{4}$. Phosphate addition is done in single drop and wise drop. The calcinations of crab shell were done at $1000{ }^{\circ} \mathrm{C}$ for 5 hours. The FTIR analysis showed that there were functional groups of $\mathrm{OH}, \mathrm{CO}_{3}{ }^{2-}, \mathrm{PO}_{4}{ }^{3-}$ and Ca-O. The XRD analysis of HAp showed that synthesis with wish drop method has the main phase of HAp and second phase is apatite carbonate. HAp that synthesized by single drop besides produce those phase also produce tricalcium bis(orthophosphate) phase. The synthesized HAp using the wise drop method has a larger surface area and pore volume but has a smaller pore size than that synthesis by using single drop method. The analyze morphology showed that HAp that synthesis using the wise drop method there is an agglomeration in morphology and the synthesis using single drop method has a smooth morphology with pores spread evenly
\end{abstract}

Keywords—crab shell, HAp, biomaterial

\section{INTRODUCTION}

HAp represented especial material of compiler of tooth and bone and represent most stable phosphate calcium compound. The HAp chemical formula is $\mathrm{Ca}_{10}\left(\mathrm{PO}_{4}\right)_{6}(\mathrm{OH})_{2}$ and the ratio of molar $\mathrm{Ca} / \mathrm{P}$ is 1.67 [1]. Excess of $\mathrm{HAp}$ is to have pore, bioactive, biocompatible, and is not corrosive [2]. The calcium source which is generally used are $\mathrm{CaO}$, $\mathrm{Ca}\left(\mathrm{NO}_{3}\right)_{2}, \mathrm{Ca}(\mathrm{OH})_{2}, \mathrm{CaCO}_{3}$ [3]. Source of the natural calcium can use for the synthesis of HAp has high calcium rate, one of them is crab shell. HAp which is synthesed of different materials has different quality. HAp which is of snail scrab has smooth and homogeneous structure while HAp which is synthesed from synthetic $\mathrm{CaO}$ has structure in form of heterogeneous [4]. In this research, Crab shell was use as source of calcium. During the time crab shell represent thrown waste to environment. The waste of crab shell contain calcium compound $\left(\mathrm{CaCO}_{3}\right)$ is about $53-78 \%$ from weight of crab shell dry of them, this calcium can be used as raw materials of HAp synthesis. Ap can synthesis by a few methods, among others dries method, sole gel, hydrothermal, and wet precipitation method [5]. In this method the calcium precursor is $\mathrm{Ca}(\mathrm{OH})_{2}$ while phosphate precursor able to be used by $\mathrm{H}_{3} \mathrm{PO}_{4}$ or $\left(\mathrm{NH}_{4}\right)_{2} . \mathrm{HPO}_{4}$ [3]. Some factor influencing: $\mathrm{pH}$, method addition of phosphate, and temperature of sintering [5]. Method addition of phosphate also has an effect on to formed HAp phase because relating to condensation homogeneity and change of $\mathrm{pH}$ at HAp synthesis. There are two method addition of phosphate that is method of wise and single drop. The method of wise drop that is phosphate condensation dripped little by little at calcium condensation, while method of single drop that is doing mixing of calcium condensation and phosphate condensation directly [6]. At this research will be done by HAP synthesis of crab shell use wet precipitation method with method variation of addition of phosphate.

\section{METHOD}

Materials which are used in this research are crab shell, some material quality p.a: $\mathrm{H}_{3} \mathrm{PO}_{4}, \mathrm{NaOH}, \mathrm{HNO}_{3}$, Aquademineneral, HAp come from Bank Jaringan of RSUD Dr. Soetomo Surabaya. Some instruments are used in this research are: Drip pipette, Thermometer, Magnetic Stirrer, Oven, meter pH, Analytic balance, FTIR Perkin Elmer Frontier-89485), XRD, SEM JEOL JSM 1600), and Surface Area of analyzer (SAA)

\section{A. Synthesis of Hydroxyapatite}

Crab shell were washed and combed till cleanness, dried under sunshine run dry. Dry Crab shell were attenuating and sieved by using sieve 100 mesh and then were calcinated on furnace with temperature $1000{ }^{\circ} \mathrm{C}$ during 5 hours. Powder which have been calcinated, carried over by desicator and deliberated until its constant mass. The synthesis HAp was done by reacting phosphate and calcium precursor with comparison of concentration of molar $\mathrm{Ca} / \mathrm{P}$ was 1.67. Condensation of $\mathrm{Ca}(\mathrm{OH})_{2}$ solution input into two chemical glass A and chemical glass B. Chemical glass A of added by direct phosphoric acid solution once added and then trap closed chemical glass to use foil and stirrer with $100 \mathrm{rpm}$ speed during 30 minute. Chemical glass of B was added with is phosphoric acid undirect drip at the same time trap closed by use alumunium foil and stirrer use stirrer magnetic with $100 \mathrm{rpm}$ speed during 30 minute. The both suspension were added by $\mathrm{NaOH}$ and $\mathrm{pH}$ monitored to use electrical meter $\mathrm{pH}$ is still $\mathrm{pH} 10$. Both suspensions were 
aged at room temperature during 24 hours to grow crystal of HAp. Sediment was filtered and washed with aquademineral until neutral. After that the sediment was washed with alcohol and dried with oven at temperature $110^{\circ} \mathrm{C}$ during 2 hours. The dry sediments are added with $\mathrm{HNO}_{3}$ for stabilization of HAp crystal. After that the HAp crystal was characterized with some instruments.

\section{RESULTS AND DISCUSSION}

The calcinations of scrab shell for produced $\mathrm{CaO}$. The $\mathrm{CaO}$ from calcination scrab shell will react with $\mathrm{H}_{2} \mathrm{O}$ to produce Calcium hydroxide solution. This solution was added with $\mathrm{H}_{3} \mathrm{PO}_{4}$ solution with wise drop and single drop methods at $60{ }^{\circ} \mathrm{C}$ until solution $\mathrm{pH}$ 7[7]. Synthesis HAp at less than $60{ }^{\circ} \mathrm{C}$ produces amorf structure, so that the synthesis HAp must do at $60{ }^{\circ} \mathrm{C}$. The HAp crystal that produce in this research there are HAp single drop (HApSD), HAp wish drop (HAp- WD ) were analysis with some instruments compared with $\mathrm{CaO}$ Scrab shell $(\mathrm{CaO}-\mathrm{CK})$ and HAp Bank Jaringan (HAp- BJ). The results of FTIR spectra in wish and single drop methods are shown in the Fig 1. This FTIR spectrum (Fig. 1) that show about the hydroxyl $(\mathrm{OH})$ functional group that absorption band in wish and single drop. There at around $3300-3570 \mathrm{~cm}^{-1}$. The FTIR spectra showed that absorption of the $\mathrm{PO}_{4}$ are $1090 \mathrm{~cm}^{-1}$, $960 \mathrm{~cm}^{-1}, 600 \mathrm{~cm}^{-1}, 560 \mathrm{~cm}^{-1}$, and $470 \mathrm{~cm}^{-1} 1090 \mathrm{~cm}^{-1}, 960$ $\mathrm{cm}^{-1}, \quad 600 \mathrm{~cm}^{-1}, 560 \mathrm{~cm}^{-1}$, and $470 \mathrm{~cm}^{-1}$, there are characteristics of spectra for hydroxyapatite. The identifying of characteristic of carbonate in HAp perceived from FTIR band of $\mathrm{CO}_{3}{ }^{2-}$ at $1400 \mathrm{~cm}^{-1}$.

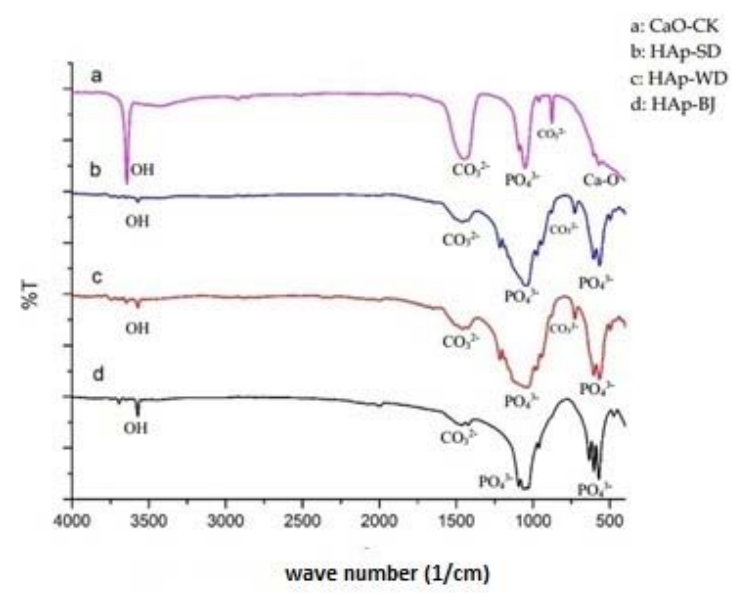

Fig. 1 FTIR spectra of CaO-CK ; HAp SD ; HAp WD and HAp BJ

Fig. 2 showed difference of diffraction pattern of $\mathrm{CaO}$ CK, HAp BJ with HAp SD and HAp WD result of synthesis. Fig. 2 show X-ray diffraction of CaO-CK most dominant phase is $\mathrm{Ca}(\mathrm{OH})_{2}$, while at HAp result of synthesis each most dominant phase in the form of HAp. At HAp-BJ sample have $2 \theta=32.056^{\circ} ; 32.361^{\circ}$; and $33.223^{\circ}$. The diffraction of HAp-SD has highest top at $2 \theta=$ $31.610^{\circ}$; $32.209^{\circ}$; and $32.459^{\circ}$; the HAp-WD has highest top at $2 \theta=31.322^{\circ} ; 32.447^{\circ}$; and $2.773^{\circ}$. The highest top of HAp-WD showed highest top of carbonate apatite same with JCPDS no. 35-0180 that characteristic of type carbonate apatite of A and of JCPDS number 19-0272 that characteristic for type carbonate apatite of B .

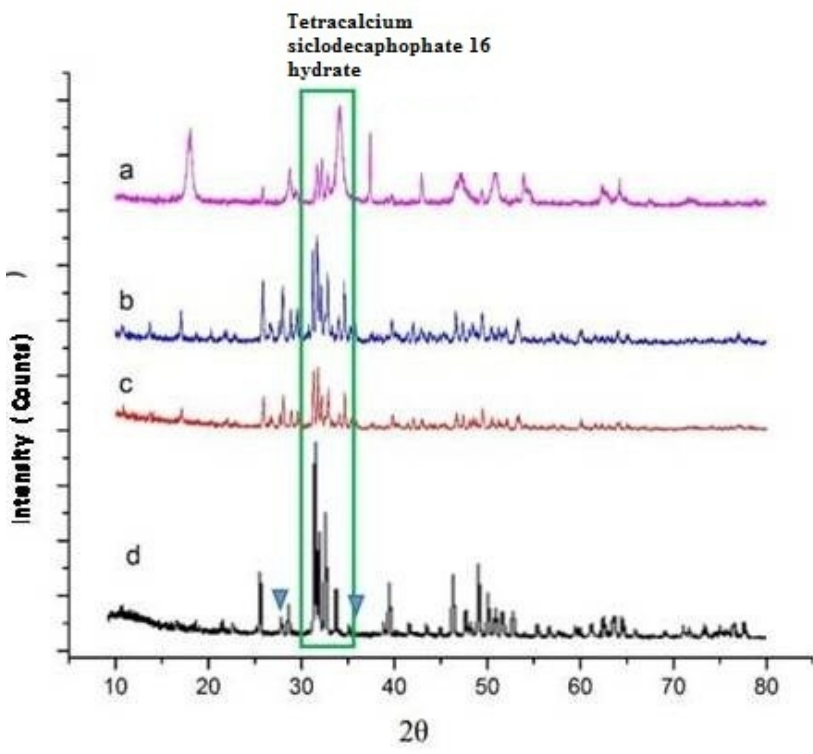

Fig 2. X-ray diffraction of CaO-CK (a); HAp-SD(b); HAp-WD (c) and HAp- BJ (d)

Analysis of phase with pan-analytycal software got result of HAp phase at HAp-WD equal to $87.37 \%$ and at HAp-SD is $62.37 \%$. According to ISO-13779:2008 application bone implant able to be minimum contain $50 \%$ HAp phase, so that both HAp results of synthesis have fulfilled bone implant standart.

Both of HAp also contains other phase in the form of carbonate apatite. Carbonate apatite come from Ion carbonate $\left(\mathrm{CO}_{3}^{2-}\right)$ which is substituted into HAp [7]. According to research existence of carbonate which is substituted in HAp (apatite carbonate) will improve growth of cell of osteoblast in test of in vitro [8].

Analysis Surface Area of Analyzer (SAA) used to know surface area, pore volume, and pore size. The result analysis by using BET method presented in Table 1

TABLE. BET ANALYSIS of HAp

\begin{tabular}{|l|c|c|}
\hline & HAp-WD & HAp-SD \\
\hline Surface $\operatorname{area}\left(\mathrm{m}^{2} / \mathrm{g}\right)$ & 1.15 & 0.50 \\
\hline Diameter pore $(\mathrm{nm})$ & 69.49 & 123.20 \\
\hline Volume pore $\left(\mathrm{mm}^{3} / \mathrm{g}\right)$ & 40.13 & 31.02 \\
\hline
\end{tabular}

From result of SAA, HAp-WD have pore size measure which is smaller than HAp-SD, but HAp-WD have larger than pore volume HAP-SD. This Matter showed that HApWD has small pore size measure but in so that have big pore 
volume and HAp-SD have big pore size measure but do not in so that small pore volume. Size diameter pore and pore volume have an effect on to opportunity entry of network dilution fasten into implant so that will influence tying that happened between implant with bone.

Pore size measure suggested for the implant of bone range from $200-400 \mu \mathrm{m}$ with pore which each other so that have pore volume and wide of big surface [5]. In this case HAp-WD powder and also of HAp-SD do not fulfill criterion standard of implant bone so that must be done modify before application become bone implant.

Analysis SEM used to know surface morphology of HAp. The analysis used by magnification 10.000X to know surface morphology of HAp (Fig.3).
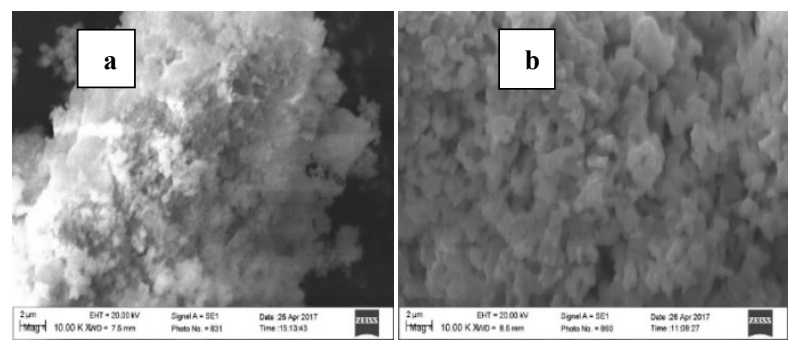

Fig. 3 SEM images of hydroxyapatite : (a) HAp-WD (b) HAp-SD, $10.000 \mathrm{X}$

Fig.3 Morphology surface (a) HAP-WD (b) HAPSD magnification 10.000X, At Fig.3 showed that surface morphology of HAp-WD seen surface of small granulated which is agglomeration while surface of uniform circular granulated HAP-SD with stand-out pore. Figure 3 seen side of surface both of HAP do not peaceful keen side so that used for the implant of bone.

\section{IV.CONCLUSION}

The results of synthesi HAp showed that hydroxyapatite can be synthesis from scrab shell with two methods added phosphate, single drop and wish drop. Both hydroxyapatite have similar characteristic of functional group there are $\mathrm{OH}, \mathrm{CO}_{3}{ }^{2-}, \mathrm{PO}_{4}{ }^{3-}$ and $\mathrm{Ca}-\mathrm{O}$.The XRD analysis of HAp showed that HAp that synthesis with wish drop method can produce the main phase of HAp and apatite carbonate. The HAp synthesized with single drop produce two dominant phase HAp and tricalcium bis (orthophosphate) phase. The analysis surface morphology with SEM showed that for wise drop method HAp that produce has a larger surface area and pore volume but has a smaller pore size than that synthesis by using single drop method. While HAp that synthesis using the wise drop method there is an agglomeration in morphology and the synthesis using single drop method has a smooth morphology .

\section{ACKNOWLEDGMENT}

The researcher wish thanks you very much to DRPM DIKTI INDONESIA for material support this research with Hibah Penelitian Berbasis Kompetensi Programme 2018 with No.Contract: 000001.92/UN38.11P/LT/2018, February 12, 2018

\section{REFERENCES}

[1] A.Yelten and S. Yilmaz, "Various Parameters Affecting the Synthesis of the HAp Powders by the Wet Chemical Precipitation Technique,"Materials Today: Proceedings 3 pp. 2869-2876.2016

[2] S.V Dorozhkin,"Bioceramic of calcium orthopsphates,", 2010, Vol 31(7) pp.1465-85.Maret.

[3] R.Othman, Z.Mustafa, C.W Loon and A.FMohd Noor, "Effect of calcium precursor and $\mathrm{pH}$ on the precipitation of carbonated hydroxyapatite," Procedia Chemistry, 2016, Vol 19 pp.539-545.

[4] K. Salma, L. B.Cimdina, and N. Borodajenko," Calcium phosphate bioceramics prepared from wetchemically precipitated powders," Processing and Application of Ceramics, 2010, vol 4.no.1 pp. 45-51.

[5] S. E Cahyaningrum, N. Herdyastuty, B. Devina and D. Supangat, "Synthesis and Characterization of Hydroxyapatite Powder by Wet Precipitation Method," IOP Conf. Series: Materials Science and Engineering, 2017, 299012039.

[6] H.Peng, J.Wang, LV Shanshan, J.Wein and J.F Chen, " Synthesis and characterization of hydroxyapatite nanoparticles pre[pared by ahighgravity precipitation method, “ Ceramic Internatioanal. Vol.41.Issue 10 part B, 2015, pp.14340-14349.

[7] S. E. Cahyaningrum, N. Herdyastuti, D. Supangat, B. Devina and M. Kurniasari, "Fabrication of nanohydroxyapatite/ scraw collagen/chitosan composite for bone graft candidate,'Rasayan Journal of chemistry, 2018, Vol 11.no.2.pp 488-493.

[8] P.Wang, C.Li, H.Gong, X. Jiang, H.Wang and K.Li ," Effect of synthesis condition on the morphology of hydroxyapaptite nanoparticles produced by wet chemical process," Powder Technology, 2010, Vol 203. Issue.2.pp.315-321. 